Journal of Engineering and Applied Sciences 15 (6): 1564-1572, 2020

ISSN: 1816-949X

(C) Medwell Journals, 2020

\title{
Acrual Basis in Accounting Information Systems and its Impact on the Quality of Information
}

\author{
${ }^{1}$ Otniel Safkaur, ${ }^{2}$ Nunuy Nurafiah, ${ }^{2}$ Sugiono Poulus and ${ }^{2}$ Muhammad Dahlan \\ ${ }^{1}$ Lecture of Departement Accounting, Universitas Cendrawasih, Jayapura, Indonesia \\ ${ }^{2}$ Lecture of Departement Accounting, Universitas Padjadjaran Bandung, Sumedang, Indonesia
}

\begin{abstract}
The implementation of regional autonomy as an embodiment of the system of good governance is characterized by the proliferation of problems with the lack of quality accounting information produced both by the central government and regional governments in Indonesia, one of the trigger factors for the lack of quality accounting information caused by the application of accounting systems not yet effective by various government agencies in Indonesia. This study aims to find out how the application of accrual basis in accounting system at the government and its influence on the quality of accounting information that it produces. This study uses the method of verifying causality to determine the effect between variables. The population in this study were as many as 44 district and city governments of Papua and West Papua provinces. Whereas the observation unit is DPKAD in 44 provinces/cities/districts in the Papua and West Papua regions. Sampling technique uses a census so that all members of the population become the study sample. The results of this study show empirical evidence that the application of accrual basis to the accounting system influences the quality of accounting information generated from the financial statements of 44 regency and city governments in the provinces of Papua and West Papua.
\end{abstract}

Key words: Accrual basis, accountig information system, financial report, quality information, statements

\section{INTRODUCTION}

Public sector organizations have been considered by the public to be unproductive inefficient, always losing, low quality, poor in innovation and creativity and various other criticisms. Therefore, Mardiasmo (2002) suggests that the implementation of regional autonomy in Indonesia can be seen as a good strategy to respond to the demands of the local community towards sharing of power, distribution of income independence of the management system in the region, strengthening the regional economy, the threat of national disintegration, public panic due to weak security and public order and legal uncertainty.

The implementation of regional autonomy is the realization of a system of good governance and is characterized by increased regional independence, transparency and public accountability, regional governments that are increasingly responsive to society increased public participation in regional development increased efficiency and effectiveness of financial management and services public and increased democratization in the region.

The application of good governance in Indonesia is accompanied by the birth of the concept of New Public Management (NPM) which is a public sector reform movement that has led to reforms in public sector accounting, meaning a period in which accounting principles that have been carried out in the private sector can be adopted by the public sector, so that, the information produced by accounting becomes a tool to measure the extent of efficiency and accountability. NPM is the beginning of the birth of a bureaucracy marked by changes in public sector accounting in several countries related to organizational accountability practices. Accountability of an organization is characterized by the obligations of an organization to be able to produce quality financial reports. The quality of financial statements is not only intended for business entities but also for public entities. Quality financial reports in the public sector, especially in government are financial reports that are able to present relevant and reliable financial information (Mardiasmo, 2002). Quality financial reports based on the International Public Sector Accounting Standards Board (IPSASB) include the following characteristics: relevance, faithful representation, understandability, timeliness, comparability and verifiability. Whereas according to Government Regulation No. 71 of 2010 there are four characteristics as normative prerequisites needed, so that, government financial reports can meet the desired quality which consists of: relevant, reliable, comparable and understandable.

The phenomenon that illustrates the low quality of financial reports was put forward by the Indonesian Forum National Secretariat for Budget Transparency 


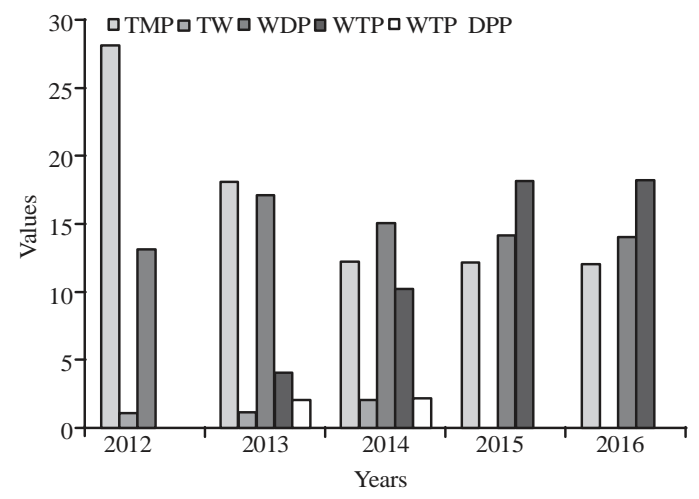

Fig. 1: LKPD opinion for 2012-2016 in Papua and West Papua provinces (\%), data process by researcher

(Fitra) Apung Widadi who considered that the financial performance of the government of Joko Widodo and Jusuf Kalla this year was the worst because the indicator was the achievement of unqualified assessment (WTP) for the Ministry and Institutions in the Jokowi-JK government experienced a decline. Minister of Home Affairs Tjahjo Kumolo also warned the regional government to be able to manage regional finance more orderly and accountable because based on data from the Corruption Eradication Commission and the Supreme Audit Agency received by the Ministry of Home Affairs, there were $77 \%$ of regional governments having problems in their financial accountability reports (www.globalindo.co/2014).

The phenomenon of the low quality of local government financial reports also occurred in Papua and West Papua provinces because based on the results of the BPK-RI examination from 2012-2016 that the average opinion was given on the financial statements of the regency and city governments in Papua and Western provinces is reasonable with exceptions (WDP), unnatural (TW) and not giving opinions (TMP). The following are developments in the results of the BPK-RI audit of the LKPD in the provinces and districts/cities in the province of Papua and Western provinces in 2012-2016 which can be seen in Fig. 1.

The quality of government financial reports can be produced through the application of accrual-based accounting systems (Robinson and Harun, 2004). Robinson and Harun (2004) argue that the use of accrual accounting is believed to be a superior information technology to create greater transparency in public sector activities which ultimately aims to improve government accountability and improve the quality of government decision making. Accrual-based accounting is an international based practice in modern financial management in accordance with the principles of the New Public Management (NPM) that promotes transparency and financial management accountability.
According to Stice et al. (2010) that the accrual basis has become the basis commonly used by companies, both large companies and small companies, both those who have gone public and those who have not gone public because the accrual basis is believed to provide a better picture regarding company performance, so companies can make policies that are more relevant for the future.

The same thing can be confirmed by Mulya (2011) the use of accrual basis is one of the characteristics of the practice of modern financial management in the public sector that aims to provide more transparent information about costs and also can improve the quality of government decision making using expanded information. Then Simanjuntak, said that accrual-based accounting can provide the most comprehensive information because all resource flows can be recorded in accordance with the time of the occurrence of these resource flows.

The implementation of accrual-based accounting in government cannot be easily implemented as in the private sector because of the challenges faced by the government to implement the system including commitment and support from the leadership and decision makers in the government, the availability of competent and professional Human Resources (HR) financial management (Bastian, 2006).

This research refers to the research conducted by Ouda and Stamatiadis (2009) in greece about accrual accounting reform in general hospitals.

\section{Litelature review}

Quality of financial statement: Financial statements are information that is used by an entity to communicate circumstances related to its financial condition to interested parties both from internal entities and external entities (Kieso et al., 2013). Accounting information is the result of an accounting process that includes the process of recording, grouping and summarizing financial data of certain entities (Kieso et al., 2013). Financial statements can also be interpreted as the end result (output) of the accounting cycle, Albercht et al..

Furthermore Wood and Homme say that financial statements can be produced by each entity, both business entities and public entities. Mardiasmo (2002) argues that financial reports in the public sector, especially government financial statements are a form of transparency as a supporting condition for accountability, namely in the form of openness of the government to public resource management activities (Mardiasmo, 2002).

Quality financial reports according to the International Public Sector Accounting Standards Board (IPSASB) are the following characteristics: relevance, 
faithful representation, understandability, timeliness, comparability and verifiability. Whereas according to Government Regulation No. 71 of 2010 concerning SAP states that there are four characteristics as normative prerequisites that are needed, so that, government financial statements can meet the desired quality consisting of: relevant, reliable, comparable and understandable.

The same thing was stated by Mardiasmo (2002) that quality financial reports in the public sector, especially in government are financial statements that are able to present reliable and reliable financial information. Wood and Hommer define the quality of financial statements as reports that fairly present the state of the entity and activities for the end of the year and provide useful information for users of financial statements. Brookson (2009) defines the quality of financial statements as reports in accordance with financial reporting accounting standards that indicate the financial position and results of operations of an entity at the end of the period.

According to Government Regulation No. 71 of 2010 concerning Government Accounting Standards that quality government financial reports are government financial reports that fulfill the desired quality, namely relevant, reliable, comparable and understandable. Furthermore Abdullah (2006) said that regional financial reports were said to be of high quality if the financial statements presented each year received an evaluation in the form of an opinion from the Financial Supervisory Agency (BPK). When the BPK provides a Fair Without Exception (WTP) opinion on the LKPD report, it means that it can be said that the financial statements of a local government entity are presented and expressed in a reasonable and quality manner.

In the opinion of Van Beest et al. (2009); International Public Sector Accounting Standards Board (IPSASB) that the quality of financial statements can be seen based on:

Relevance: Relevance is referred to as the capability "of making a difference in the decisions madeby users in their capacity as capital providers. Relevance is operationalized using four items referring to predictive and confirmatory value.

Faitful representation: Faithful representation is the second fundamental qualitative characteristic as elaborated in the conceptual framework for financial reporting. To faithfully represent economic phenomena that information purports to represent, annual reports must be complete, neutral and free from material error. Faithful representation ismeasured using five items referring to neutrality, completeness, freedom from material error and verifiability.
Understanbility: The first enhancing qualitative characteristic, understandability will increase when information is classified, characterized and presented clearly and concisely. Understandability is referred to, when the quality of information enables users to comprehend their meaning. Understandability is measured using five items that emphasize the transparency and clearness of the information presented in annualreports.

Comparability: A second enhancing qualitative characteristic is comparability which "is the quality of information that enables users to identify similarities in and differences between two sets of economic phenomena". Comparability is measured using six items that focus on consistency.

Timelines: The final enhancing qualitative characteristic defined in the conceptual framework for financial reporting is timeliness. "Timeliness means having information available to decision makers before it loses its capacity to influence decisions. Timeliness refers to the time it takes to reveal the information and is related to decision usefulness in general”.

Accrual-based accounting: Accrual accounting basis according to government regulator or PP No. 71 of 2010 concerning government accounting standards is an accounting basis in which economic transactions and other events are recognized, recorded and presented in the financial statements at the time of the transaction, regardless of the time cash or cash equivalents are received or paid. Changes from cash-based accounting or budget accounting to accrual accounting are often important elements in public sector reform (Robinson and Harun, 2004).

Jones and Pandlebury (2010), Rkein, (2008) said that accrual-based accounting is based on recognition of income and resources consumed in one period rather than cash receipts and payments. Accrual accounting is the basis of accounting where assets, liabilities, equity income and expenses are recognized in the interrelated periods.

Accrual basis according to the International Public Sector Accounting Standards (IPSAS) is "accrual basis basis of accounting under which transactions and other events are recognized when they occur (and not only when cash or equivalent is paid). Therefor, the transactions and events are recorded in the accounting concepts and are recognized in the financial statements of the periods to which they relate. The elements are recognized under accrual accounting are assets, liabilities, netassets/equity, revenue and expenses ". Then the accrual basis according to Skousen et al. "accrual accounting recognizes revenues as they are earned, not necessarily when cash is received. The expenses are recognized and recorded they are incurred, notably when cash is paid. 
Accrual accounting provides results in financial statements that more accurately reflect company's financial position and results of operations”.

Accrual accounting recognizes income because the income is earned, not necessarily when money is received. Costs are recognized and recorded when they occur, not necessary when cash is paid. Accrual accounting provides better matching of income and expenses during the accounting period and generally produces financial statements that more accurately reflect the financial position and results of the company's operations. According to Weyandt et al. (2012). “Accrual-basis accounting means that transactions that are financial statements are not recorded”. Even if cash is not exchanged".

Accrual-based accounting according to Ritonga (2010) that accrual-based accounting means income, expenditure, financing, assets, liabilities and equity funds are recognized and recorded at the time of transactions without regard to when cash or cash equivalents are received or paid. While Simanjuntak defines accrualbased accounting as an accounting basis in which economic transactions and other events are recognized, recorded and presented in the financial statements at the time of the transaction, regardless of the time cash or cash equivalents are received or paid. Accrual-based accounting is the basis on which all economic transactions and other events can be recognized, recorded and can be presented in the financial statements at the time of the transaction, regardless of the time when cash or cash equivalents are received or paid.

In Article 1 PP 71 of 2010 explains that Accrual-based Government Accounting Standards are government accounting standards that recognize income, expenses, assets, debt and equity in accrual-based financial reporting and recognize income, expenditure and financing in reporting budget execution based on the basis stipulated in the APBN/APBD.

From all the definitions above, it can be said that in accrual-based accounting, the recording time is in accordance with the current occurrence of resources, so that, it can provide the most comprehensive information from all recorded resource flows. Accordingly income is recognized when earned income and expenses or expenses are recognized when the obligation arises or resources are consumed.

Based on the explanation above, it can be concluded that the focus of accrual-based accounting systems is on measuring economic resources and changing power in an entity. Accounting is also an accounting system that recognizes and presents economic transactions or events when an event occurs without seeing cash or cash equivalents obtained or issued (Jones and Pandlebury,
2004; Ritonga, 2010; Harun, 2009; Robinson and Harun, 2004). According to Ouda there are three (3) accrual-based accounting implementation dimensions including:

Establishment phase: In this stage it can be shown how to find out the basic technical requirements in the formation of accrual accounting in government where this stage shows a change in the preparation of financial statements from cash toward accrual to the accrual basis.

Conversion phase: This stage includes the transfer of data from the cash modification system and additional accounting files which consist of account details such as debtors and creditors and others for accrual systems. Information available in the current cash system and additional files will form the starting point for the accrual system. Therefore, this stage will provide a link to transfer data periodically from the old accounting system to the new accounting system. This stage includes the migration of applications from the old system to the new system. This migration process, if it is not carefully prepared, will experience problems, especially in terms of databases.

Testing and confirmation phase: This stage includes testing the workability of the accrual system in order to obtain an agreement to switch to a new system. The computerized system chosen to handle accrual accounting consists of new software and modification of existing cash systems.

Effect of accrual based accounting implementation on the quality of financial statements. The quality of government financial reports can be produced through, the application of accrual-based accounting systems (Robinson and Harun, 2004). Robinson and Harun (2004) argue that the use of accrual accounting is believed to be a superior information technology to create greater transparency in public sector activities which ultimately aims to improve government accountability and improve the quality of government decision making.

The usefulness of financial statements is determined by the content of the information presented in the financial statements. In order for these financial statements to contain useful information, the financial statements must be guided by applicable accounting standards. The use of accrual accounting in the public sector involves the application of the same financial accounting standards as in the commercial sector and this facilitates comparisons between the costs of providing public services and the costs of services purchased directly from non-public sources (Newberry and Pallot, 2005).

The application of accrual accounting is the right approach in order to increase accountability, improve transparency of financial statements, calculate service 
costs, operational budgeting, prioritize activities and programs and optimize future decisions (Abolhalaje et al., 2012). Accrual-based accounting has the advantage of improving government financial reporting (Ouda) and providing more complete, objective and transparent financial information (Christiaens and Peteghem, 2003) and increasing transparency and accountability. The advantage of accrual accounting is that it makes financial reports reliable, relevant, understandable and comparable (Ouda). Without adequate and successful implementation, the new accounting system cannot provide accurate and relevant information.

Accrual accounting has benefits that include increased transparency, both external and internal accountability, greater organizational performance, resource allocation and greater efficiency improvements derived from the ability of public entities to identify the full costs of their activities. Managerial decision making because of the better quality of financial information generated from financial accrual reports and accurate, comparable and useful information for users of financial statements that are realized.

Furthermore, accrual accounting can increase accountability and improve performance in the public sector because it will increase the availability of reliable financial information for decision-making purposes. The main benefits obtained from implementing accrual accounting based on increasing transparency increasing consistency and comparability of financial information, accrual accounting results for increased resource allocation and also increasing accountability.

In addition, one of the main reasons that organizations adopt accrual accounting is to increase internal and external transparency increase the accountability of countries and non-profit entities (Newberry and Pallot, 2005). Accrual accounting describes the need for transparency, efficiency and management performance and the information provided by accrual-based systems is more comprehensive and of higher quality and consistency (Christiaens et al., 2003). Accrual basis accounting is used to apply criteria for measuring economic resources in integrated financial reporting of an organization can play an important role in increasing accountability in the public sector. Accrual accounting provides sufficient information to present accurate financial positions of public sector organizations. Accrual accounting allows an assessment of the actual financial position of the public sector including the level of loans and other obligations. Financial reports provide historical information relating to organizational performance. Accrual accounting requires disclosure of financial information through notes to financial statements. The financial performance statement shows the income and expenses of a public entity while the financial position report shows the assets and liabilities of the entity. Accrual accounting also requires reporting entities to provide disclosure records relating to information presented in financial statements.

The main benefits of implementing accrual-based accounting include transparency increasing consistency and comparison of financial information (Stamatiadis et al., 2009). Accrual accounting provides sufficient information to present accurate financial positions of public sector organizations. Accrual accounting systems reflect long-term organizational commitment and the overall financial situation is more accurate (Mohammadi et al., 2012). Accruals provide more complete and comprehensive cost and performance information and as a powerful tool for identifying scope and increasing efficiency and making better use of resources.

The results of Ofoegbu's research, Grace show that there is a positive and significant influence on the implementation of accrual-based accounting with the quality of financial statements. Accrual-based accounting implementation has implications for the quality of LKKL because the better the implementation of accrual-based accounting, the more it will improve the quality of LKKL (Najati et al., 2016). Based on the disclosed framework, it can be predicted that the implementation of accrualbased accounting affect the quality of financial statements. Therefore, the hypothesis formulation is arranged as follows:

- $\mathrm{H}_{1}$ : the better the implementation of accrual-based accounting, the better the quality of information

\section{MATERIALS AND METHODS}

Research methods, population and sample: This study aims to test hypotheses (hypotheses testing) which are developed based on theories and previous research. The research method used is explanatory research and causal study, namely research that states what and how far factors are expected to influence a variable with the aim of testing the hypothesis (Kuncoro, 2003).

Field studies are carried out at the provincial/city/regency government. The unit of analysis in this study is the provincial/city/district government in the west Papua and Papua region. The time horizon of this study is a one shot study or cross sectional study which is a study conducted with data that is only once collected during one period in order to answer research questions.

The target population (target population) are as many as 44 district and city governments in Papua and West Papua provinces. While the observation unit or data collection unit is DPKAD in 44 provinces/cities/districts in the Papua and West Papua regions. Furthermore, the sample of this study was that all members of the population amounted to 44 district and city governments 
in the provinces of Papua and West Papua to be studied, thus, the samples were saturated samples or census techniques.

The unit of observation in this research is the Regional Inspectorate and the Regional Financial and Asset Management Agency (BPKAD). Respondents for each include: for the Inspectorate represented by the Head of the Inspectorate, while for BPKAD, represented by the agency and 3 heads of fields namely Head of Accounting, Head of Budget and Treasury. So that, from each local government made the respondent is 5 people. So, the total number of respondents is $44 \times 5$ people $=220$ people.

The type of data used in this study is primary data and secondary data (Sekaran and Bougie, 2010). Primary data used in this study were taken directly from the respondents in the form of their responses to a number of research questions related to the variable accrual-based accounting $(\mathrm{X})$ and financial report quality (Y). Secondary data used in this study is data about the local government examination report to measure financial report quality variables $(\mathrm{Y})$ where the data is taken from the Republic of Indonesia Financial audit Agency (BPK-RI). Qualitative or primary data is obtained from respondents with data collection techniques as follows:

Questionnaire which is a structured list of questions or statements (items) addressed to Regional Financial Management Officials (PPKD) and Regional Supervisory Bodies/District and City Regional Inspectorates in the provinces of Papua and West Papua.

Interviews, namely direct discussions with Regional Financial Management Officers (PPKD) and Regional Supervisory Bodies/Regency and City provinces throughout the provinces of Papua and West Papua.

Observation, carried out by looking closely and learning things related to the subject matter that was conducted in each local government that became the object of research.

Documentation, namely data from existing sources obtained through BPK-RI regarding and report of LKPD examination results and report on the Effectiveness of Internal Control Systems of Governments in the provinces of Papua and West Papua.

Data analysis: Primary data collected through, distributing questionnaires need to be tested first with consideration that the sincerity of respondents in answering questions is very important in this study. For this reason, it takes two types of testing, namely the validity test (test of validity) and reliability testing (test of reliability). In this study as for those tested for validity and reliability are the variables of the application of accrual-based accounting, employee competency.

In this study two types of analysis were conducted to obtain results that were in accordance with the research objectives, namely: descriptive analysis to explain the characteristics of the variables studied to support problem solving to obtain operational suggestions and verification analysis through modeling component-based Structural Equation Modeling (SEM) or variance known as Partial Least Square (PLS) in order to answer the problem statement and answer the hypothesis.

Component or variance based Structural Equation Modeling (SEM) equation was chosen based on the limitations of the number of samples, where only 44 samples were sampled and did not qualify using Structural Equation Modeling (SEM) based on covariance for the second order factor model type. Partial Least Square (PLS) was first developed by Wold as a general method for estimating path models that use latent constructs with multiple indicators. According to Wold Partial Least Square (PLS) is a powerful analytical method because it is not based on many assumptions. Data does not have to be normally multivariate (indicators with category, ordinal scale intervals until the ratio can be used on the same model), the sample does not have to be large.

Hypothesis testing: The hypothesis is formulated into operational equations as follows:

- $\mathrm{H}_{0} \gamma_{1.1} \leq 0$ : There is no positive influence on the Implementation of accrual based in accounting systems on the quality of information (financial statements)

- $\quad \mathrm{H}_{1} \gamma_{1.1}>0$ : There is a positive influence on the Implementation of accrual based in accounting systems on the quality of information (financial statements)

Tests are not carried out using the t test but by comparing the magnitude of the influence value whether it is $>0$ or not. If the amount of influence is equal to 0 or smaller then $\mathrm{H}_{0}$ is accepted but if the opposite path coefficient is greater, then $\mathrm{H}_{0}$ is rejected.

\section{RESULTS AND DISCUSSION}

Evaluation of outer models. In this study there are 2 latent variables namely the application of accrual-based accounting (X1) and the quality of financial statements (Y). The first stage of evaluation of the measurement model is to evaluate the convergent validity criteria. Based on the estimation results using the help of the Smart PLS 2.0 program application. Obtained output as shown in Fig. 2 and Table 1. Recapitulation The value of convergent validity for each indicator and latent variable is shown in below: 


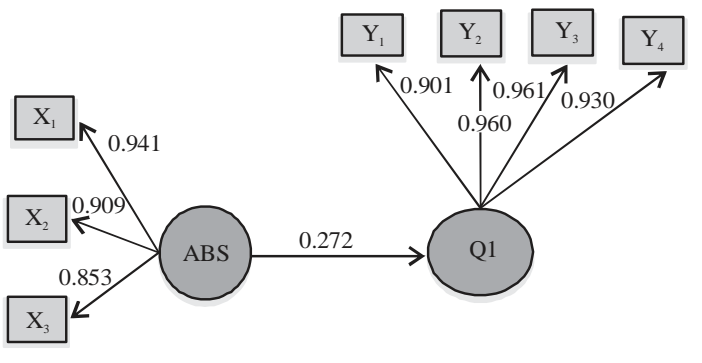

Fig. 2: Complete model path diagram

Table 1: Value of cross loadings evaluation of outer models

\begin{tabular}{llllll}
\hline & \\
\hline $\mathrm{X}_{1}$ & 0.450 & 0.402 & 0.187 & 0.212 & $\mathbf{0 . 9 4 2}$ \\
$\mathrm{X}_{2}$ & 0.457 & 0.447 & 0.247 & 0.245 & $\mathbf{0 . 9 0 9}$ \\
$\mathrm{X}_{3}$ & 0.396 & 0.219 & 0.252 & 0.123 & $\mathbf{0 . 8 5 3}$ \\
$\mathrm{Y}_{1}$ & 0.564 & $\mathbf{0 . 9 0 1}$ & 0.408 & 0.381 & 0.445 \\
$\mathrm{Y}_{2}$ & 0.585 & $\mathbf{0 . 9 6 0}$ & 0.385 & 0.421 & 0.359 \\
$\mathrm{Y}_{3}$ & 0.581 & $\mathbf{0 . 9 5 1}$ & 0.447 & 0.426 & 0.430 \\
$\mathrm{Y}_{4}$ & 0.587 & $\mathbf{0 . 9 3 0}$ & 0.378 & 0.534 & 0.337 \\
\hline
\end{tabular}

Table 2: Value of composite reliability and Average Variance Extracted (AVE

\begin{tabular}{lcc}
\hline Values & Composite reliability & Avarage Variance Extracted (AVE) \\
\hline ABS $\left.X_{1}\right)$ & 0.929 & 0.813 \\
QI $(Y)$ & 0.964 & 0.871 \\
\hline
\end{tabular}

Table 3: Path coefficients value

\begin{tabular}{lc}
\hline Values & ABS $\left(\mathrm{X}_{1}\right) \rightarrow \mathrm{QI}(\mathrm{Y})$ \\
\hline Original sample & 0.272 \\
Sample mean & 0.272 \\
SD & 0.101 \\
SE & 0.101 \\
t-statistics & 2.693 \\
\hline
\end{tabular}

Based on Fig. 2 and Table 1, it appears that all indicators of loading factor measurements have values above 0.50 in each of the boarding houses. Thus, it can be concluded that all constructs have good convergent validity. The value of cross loadings also shows good discriminant validity because the value of indicator correlation with its construct is higher than the value of indicator correlation with other constructs (Gazali, 2011). The next step is to assess composite reliability criteria and Average Variance Extracted (AVE). The composite reliability value and Average Variance Extracted (AVE) are shown in Table 2:

From the results above, it is obtained information that the AVE value generated by the latent variable exceeds the standard 0.5 and the composite reliability value and cronbach alpha above the minimum limit of 0.7 , so that, the overall latent variable is the application of accrual based accounting (X) and the quality of financial statements $(\mathrm{Y})$ has met the requirements of the validity and reliability of the measurement model. Evaluate the inner model. The relationship between constructs can be said to be significant if it has a value of t-statistics $>1.96$. The following Table 3 can be seen from the estimation of the relationship between constructs by presenting the path coefficient and t-statistics.
Table 4: Hypothesis testing result

\begin{tabular}{lc}
\hline Latent variable & $\mathrm{X}_{1}>\mathrm{Y}$ \\
\hline Path coefficient & 0.272 \\
$\mathrm{~T}_{\text {count }}$ & 2.693 \\
$\mathrm{t}_{\text {critical }}$ & 1.960 \\
\hline
\end{tabular}

PLS software

Based on the path coefficients values shown in Table 3 above, the estimation of the relationship between constructs will be explained which gives an illustration of the influence between the accrual basis of the quality of information at 0.272 .

Hypothesis testing: The results of testing the hypothesis are shown in the following Table 4. From the table above, it can be seen that the calculated $t$ value obtained by the application of accrual-based accounting variable (X) is 2,693 . This value is greater than t-table value 1.960 . In accordance with the testing criteria of the hypothesis that $\mathrm{H}_{0}$ is rejected and Ha is accepted, meaning partially, the application of accrual-based accounting has a significant effect on the quality of financial reports in the provincial/district/city governments in Papua and West Papua.

Discussion: Based on the description above, it can be concluded that the application of accrual-based accounting has a significant effect on the quality of financial reports in the provincial/regency/city governments in Papua and West Papua. The results of this study are in line with various theories which state that the application of accrual-based accounting can create better transparency towards public sector activities in order to be able to measure the use of capital resources in order to be able to compare the benefits and costs of each activity or output of the public sector.

The focus of accrual-based accounting systems is on measuring economic resources and changing power in an entity. Accounting is also an accounting system that recognizes and presents economic transactions or events when an event occurs without seeing cash or cash equivalents obtained or issued (Jones and Pandlebury, 2004;, Weygant et al., 2011; PP No. 71 of 2010; Ritonga, 2010; Harun, 2009; Robinson and Harun, 2004).

Some results of research such as those carried out by Ofoegbu (2014), Najati et al. (2016); Ifa Ratifah, concludes that the implementation of accrual-based accounting has a positive and significant effect on the quality of financial statements.

The results of this study are in line with the theory as stated by (Harun, 2009) financial statements are the main accountability tool of the government to people's representatives in parliament or to other state institutions of interest and the general public to have an interest in assessing government performance. Mardiasmo (2002) says that one of the tools to facilitate the creation of 
public accountability is through the presentation of comprehensive regional government financial reports. Whereas according to PP 71 in 2010 affirms that financial statements are mainly used to determine the value of economic resources that are used to carry out government operational activities, assess financial conditions, evaluate the effectiveness and efficiency of a reporting entity and help determine compliance with laws and regulations.

\section{CONCLUSION}

Based on the results of data analysis and discussion described earlier, the authors conclude that the application of accrual-based accounting has a significant effect on the quality of financial statements which shows that the better the application of accrual-based accounting, the better the quality of government financial reports.

\section{RECOMMENDATIONS}

The operational advice given is to increase the role of the Regional Personnel Agency by developing strategies related to HR competencies which include planning to fulfill the needs of the number of $\mathrm{HR}$ based on competencies, compiling education and training qualifications based on predetermined standards and certifications, providing periodic databases on HR competencies to support the process mutations and rotations based on needs and providing assistance in the preparation of accrual-based financial statements by competent parties to realize good governance.

This study proves that the application of accrualbased government accounting, competency of human resource personnel and the government's internal control system affect the quality of financial statements and the quality of financial statements affect good governance. The results of testing this hypothesis contribute to the development of accounting science, especially in the field of public accounting. Furthermore, the results of this study can also be used as a foundation by other researchers who are interested in conducting research in the field of public accounting by using the same research methods in different analysis units and samples in the hope that they will obtain the same results (replicability). Thus, continuous research activities such as this can increase confidence in the research that has been carried out and the usefulness of the results of research can be widely accepted because the scope of research success is generally, accepted (generalizability).

\section{REFERENCES}

Abdullah, S., 2006. [Legislative opportunistic behavior in regional budgeting: Empirical evidence for agency theory applications in the public sector (In Indonesian)]. SSRN Electron. J., 1: 1-25.
Abolhalaj, M., M. Ramezanian and P. Bastani, 2012. Accrual accounting accomplishments in Iranian Universities of Medical Sciences: A mixed method study. Middle East J. Sci. Res., 12: 294-300.

Bastian, I., 2006. [Public Sector Accounting: An Introduction]. Penerbit Erlangga, Jakarta Indonesia, (In Indonesian).

Beest, F.V., G.J.M. Braam and S. Boelens, 2009. Quality of financial reporting: Measuring qualitative characteristics. MBA Thesis, Radboud University Nijmegen, Nijmegen, Netherlands.

Brookson, S., 2009. Understanding Accounts. Dorling Kindersley Limited, London, UK., ISBN:9781405352239, Pages: 72.

Christiaens, J. and V. Van Peteghem, 2003. Governmental accounting reform: Evolution of the implementation in flemish municipalities. Financial Accountability Manage., 23: 375-399.

Christiaens, J., 2007. Governmental accounting reform, evolution of the implementation in flemish municipalities. Financial Accountability Manage., 23: 99-111.

Gazali, I., 2011. [Multivariate Analysis Application with IBM SPSS 19 Program]. 5th Edn., Badan Penerbit Universitas Diponegoro, Semarang Indonesia, (In Indonesian).

Halim, A. and M.S. Kusufi, 2012. [Theories, Concepts and Applications of Public Sector Accounting From Budgets to Financial Reports, from the Government to Places of Worship]. Penerbit Salemba, South Jakarta Indonesia, ISBN:978-979-061-227-3, Pages: 466 (In Indonesian).

Halim, A. and S. Abdullah, 2006. [Relationship and agency problems in local government: A budget and accounting research opportunity (In Indonesian)]. Government Accounting J., 2: 53-64.

Hardani, M.W. and N.I. Sallama, 2010. [Regional Financial Management]. Erlangga Publisher, Jakarta Indonesia, ISBN:9789790751781, Pages: 196 (In Indonesian).

Harun, 2009. [Accounting Reform and Public Sector Management in Indonesia]. Salemba Empat, Jakarta Indonesian, ISBN:9789790610361, Pages: 218 (In Indonesian).

Hassan, H.A.G., 2010. A prescriptive model of the transition to accrual accounting in central government. Intl. J. Government Financial Manage., 10: 63-94.

Jones, R. and M. Pendlebury, 2004. A theory of the published accounts of local authorities. Financial Accountability Manage., 20: 305-325.

Kieso, D.E., J.J. Weygandt and T.D. Warfield, 2013. Intermediate Accounting. 15th Edn., John Wiley \& Sons, Hoboken, New Jersey, USA., ISBN-13:978-1118147290, Pages: 1608. 
Kuncoro, M., 2003. [Research Methods for Business and Economics]. Erlangga Publisher, Jakarta Indonesia, Pages: 312 (In Indonesian).

Mardiasmo, 2002. [Autonomy and Regional Financial Management]. Penerbit Andi, Yogyakarta Indonesia, ISBN:9789795338116, Pages: 334 (In Indonesian).

Mohammadi, S., M. Maher and S. Zare, 2012. Implementation of full accrual basis in governmental organizations (Case study: Shiraz University of Technology, Iran). Interdiscip. J. Contemp. Res. Bus., 4: 287-298.

Mulya, B., 2011. [Use of accrual accounting in other countries: Trends in OECD members]. J. Accrual Accounting, 1: 1-28 (In Indonesian).

Najati, I., E. Pituringsih and Animah, 2016. [Accounting implementation based on accrual: Testing of determinants and its implementation on accrual based accounting finance ministry/institution (In Indonesian)]. Jember Accounting J., 14: 1-18.

Newberry, S. and J. Pallot, 2005. A wolf in sheeps clothing? Wider consequences of the financial management system of the New Zealand central government. Financial Accountability Manage., 21: 263-277.

Ofoegbu, G.N., 2014. New public management and accrual accounting basis for transparency and accountability in the Nigerian public sector. IOSR. J. Bus. Manage., 16: 104-113.

Osborne, D. and T. Gaebler, 1992. Reinventing Government: How the Entrepreneurial Spirit is Transforming the Public Sector. Addison-Wesley, New York, USA.,.

Ritonga, I.T., 2010. [Regional Government Accounting]. Gadjah Mada University, Yogyakarta Indonesia, ISBN :9786028683289, Pages: 226 (In Indonesian).

Rkein, A., 2008. Accrual accounting and public sector reform: Northern Territory experience. Ph.D Thesis, Charles Darwin University, Australia.

Robbins, W.A. and K.R. Austin, 1986. Disclosure quality in governmental financial reports: An assessment of the appropriateness of a compound measure. J. Accounting Res., 24: 412-421.
Robinson, P. and Harun, 2004. Reforming the Indonesian public sector: The introduction of accrual accounting. Proceedings of the 4th International Asia Pacific Conference on Interdisciplinary Research in Accounting (APIRA2004), July 4-6, 2004, Singapore Management University, Singapore, pp: 1-37.

Sadjiarto, A., 2000. [Accountability and government performance measurement (In Indonesian)]. J. Accounting Finance, 2: 138-150.

Salam, D.S., 2004. [Indonesian Government Management]. Penerbit Djambatan, Jakarta Indonesia, ISBN:9789794285152, Pages: 384 (In Indonesian).

Sekaran, U. and R. Bougie, 2013. Research Methods for Business: A Skill-Building Approach. 6th Edn., Wiley Publishing Company, Hoboken, New Jersey, USA., ISBN:9781119942252, Pages: 436.

Solikin, I., 2008. [The effect of government accounting implementation, quality of accounting information and quality of regional government apparatus on good government governance and its implications for financial performance]. Master Thesis, Post-Graduate Economics Program in Padjadjaran University, Bandung Indonesia.

Stamatiadis, F., 2009. Investigating the governmental accounting reform of greek national health system (ESY): Some preliminary evidence. Intl. J. Governmental Financial Manage., 9: 73-97.

Stamatiadis, F., N. Eriotis and D. Vasiliou, 2009. Assessing accrual accounting reform in Greek public hospitals: An empirical investigation. Intl. J. Econ. Sci. Appl. Res., 4: 153-184.

Stice, E.K., J.D. Stice and K.F. Skousen, 2010. Intermediate Accounting. 17th Edn., Cengage Learning, Mason, Ohio, ISBN:9780324592375, Pages: 1346.

Van Der Hoek, M.P., 2005. From cash to accrual budgeting and accounting in the public sector: The Dutch experience. Public Budgeting Finance, 25: 32-45.

Weygandt, J.J., P.D. Kimmel and D.E. Kieso, 2012. Accounting Principles. 10th Edn., John Wiley \& Sons, Hoboken, New Jersey, USA.,.

Wynne, A., 2008. Accrual accounting for the public sector-a fad that has had its day. Intl. J. Governmental Financial Manage., 8: 117-132. 